\title{
Effect of Age of Spawned Catfish (Clarias Gariepinus) Broodstock on Quantity of Eggs and Milt Produced and Growth Performance of Fry
}

\author{
Jokthan G. E \\ National Open University of Nigeria,
}

\begin{abstract}
A study was conducted to determine the effect of age of catfish (Clarias gariepinus) broodstock on quantity of eggs and milt produced and subsequent growth of fry. Six ponds were used to stocked with different ages of male and female broodstock which varied from 12 to 30 months. A completely randomized design (CRD) was used. A total of thirty six male and female broodstock each were used. There were four replicates per treatment. Spawning was induced by the use of ovaprim ${ }^{\circledR}$ injection. The eggs were fertilized with milt collected from the male broodstock. The quantities of eggs and milt produced, eggs hatched and raised to fry stage were monitored. A proximate analysis of the feed indicated that Artemia contained $55.27 \%$ crud protein and $27.12 \%$ Nitrogen Free Extract, while Dizengoff had 57.06 crude protein and $12.61 \%$ Nitrogen Free Extract. The content of crude fibre was 4.01 and $0.90 \%$ for Artemia and Dizengoff repectively. Result showed that age of female catfish broodstock positively affected the number of eggs produced with 24 and 30 months old broodstock producing 260 and $300 \mathrm{~g}$ of eggs respectively, while 15 and 18 months old had 150 and $160 \mathrm{~g}$ of eggs respectively. Hatchability also increased with age of broodstock. The older the female, the higher the egg hatchability. Fry obtained from 24 and 30 months old broodstock had a significantly $(p<0.05)$ higher weight (18g and 24g) at four weeks of age compared to fry obtained from 15 and 18 months old female broodstock which weighed $8.33 \mathrm{~g}$ and $10.00 \mathrm{~g}$ respectively. In order to obtain good egg number, high hatchability and optimum performance of the fry it is recommended that broodstock should be at least 24 months of age before being used for breeding.
\end{abstract}

Keywords: Clarias gariepinus, Age of broodstock, performance.

\section{Introduction:}

Fish farming is a fast emerging enterprise with lots of potentials in a developing country like Nigeria. Apart from empowering the people in terms of employment, it is also a source of good quality animal protein in the diet (Jokthan, 2010). Fish meat is lean, low in cholesterol and is also regarded as a safe source of animal protein particularly since the last incidence of bird flu in the Nigerian poultry industry (Bolorunduro et al. 2001). The aquaculture sector is environmentally friendly with relatively low incidence of disease outbreak. Omole et al. (2006), reported that fish meat is non zoonotic.

In order to meet its full potential, the fish production enterprise calls for distinct attention in the area of hatchery operations. The quality of broodstock affects to a very large extent the quality of fingerlings sold to farmers and the subsequent performance of the fingerings at the farmer's level. Operations of the hatchery if well understood and exploited would serve as the bedrock of this important enterprise. It is therefore, necessary to intensify research on the best age at which female catfish produce the optimum quantity and quality of eggs that will result in good hatchability and subsequent performance of fry with a view to increasing production efficiency and profitability for farmers. This study is aimed at evaluating the effect of age of female and male broodstock on quantity of eggs and milt produced, hatchability and growth rate of catfish fry

\section{Materials and Method}

This study was conducted at Rido village, a satellite town in Kaduna State, Nigeria. Different ages of male and female broodstock were kept separately in plastic PVC tanks. A total of thirty six male and female broodstock each were used. The broodstock were acclimatized for a period of two weeks before the commencement of the study The broodstock were kept separately to avoid violence. A gutter with a dimension of $200 \times 50 \times 30 \mathrm{~cm}$, was used for the incubation of the eggs. It was fitted with an overflow that had a screen which prevented the larvae from escaping.

All the fish were fumigated with formalin $(75 \mathrm{ppm})$ for three hours, to prevent pathogens from being transmitted to the eggs and larvae. The females were restrained, held with a towel placed on a heir back. A thumb was used to press the abdomen moving towards the tail. The appearance of greenish eggs indicated that the female was ready for inducement. After 24 hours, the selected females were injected with ovaprin at the rate of $0.5 \mathrm{ml} / 1 \mathrm{~kg}$ of live weight. The females were retained in the container for about 12 hours at a room 
temperature of about $30^{\circ} \mathrm{C}$. Eggs were then expressed from the abdomen into a clean bowl by gently pressing the abdomen until blood appeared signifying an empty abdomen. The quantity of eggs obtained from each female was weighed using a digital scale

Males were dissected using a pair of scissors to the internal organs. The intestines were pulled aside to reveal two yellow pinkish testes lobes which were collected and wrapped in tissue to dry for about 30-60 seconds. Any (no avoiding) form of contact with water was avoided. With a small incision, the lobes were squeezed with the fingers and the milt collected. The milt was then evenly distributed on the eggs in the bowl. Some clean water was added to mix the egg and milt by gently swirling the content of the bowl; the fertilized eggs were then poured in a single layer into the incubation gutter. The incubation was carried out at a flow through rate of $21 /$ minute; and temperature was within the range of $30^{\circ} \mathrm{C}$ to $33^{\circ} \mathrm{C}$.

Artemia was fed to the fry 4 times daily during the first 2 weeks of life. They were thereafter, introduced to Dizengoff starter feed for the next 2 weeks. Weight of fry (Average mean weight) were taken weekly by means of a digital scale.

\section{Data Collection and Statistical Analysis}

Age of the male and female broodstock as well as their respective weights were recorded taken. Correlation was carried out between weight of broodstock and the quantity of milt and weight of eggs produced. Growth of the fry was monitored for 4 weeks. Data collected was analyzed using SAS (2006).

\section{Results and Discussion}

The proximate composition of the diets presented in Table 1 showed that the percentage crude protein in Artemia was slightly lower than that of Dizengoff starter feed fed for 1-14 days. This might be because at this stage the fry required a higher level of crude protein to sustain rapid development and growth. Practical Guide to Nutrition, Feeds and Feeding of catfish delete report of (2011) indicated that it is essential to provide a complete diet for catfish because they can synthesize only a small portion of the required nutrients since the quantity of nutrients from natural food organisms in the pond is relatively small. Dietary protein requirement for various stages of catfish (Fry- table size) ranges from about 25-50 percent. Catfish fry in hatcheries are fed finely ground meal- or flour-type feeds containing 45-50 percent protein. The result indicated that the crude protein content of the starter feed was within recommended level. The crude fibre (CF) of the larva - fry stage of Artemia was higher than the recommended level of $2.5-2.7$. Omole et al. (2006), had indicated that fry can accommodate higher amounts (7\%) of crude fibre in their diet.

The age of the female broodstock catfish affected the weight of the broodstock, the quantity of eggs produced, as well as the growth performance of the fry is indicated in Table 2. The age of the male broodstock catfish also significantly affected the weight of the males and the quantity of milt produced Table 3.

Table 1: Proximate Analysis (\%) of Artemia and Dizengoff Feeds

\begin{tabular}{lllllll}
\hline Feed Type & Dry Matter & Crude protein & Crude fibre & EE & Ash & NFE \\
\hline Artemia & 90.06 & 55.25 & 4.31 & 8.09 & 5.23 & 27.12 \\
$\begin{array}{l}\text { Dizengoff } \\
\text { starter }\end{array}$ & 91.61 & 57.06 & 0.90 & 8.11 & 12.61 & 21.32
\end{tabular}

NB: NFE - Nitrogen Free Extract, EE - Ether Extract

Table 2: Effect of age of female Catfish broodstock on quantity of eggs produced

\begin{tabular}{lll}
\hline Age (Months) & Weight $(\mathrm{Kg})$ & Egg weight $(\mathrm{g})$ \\
\hline 15 & 1.5 & $150^{\mathrm{b}}$ \\
18 & 1.6 & $160^{\mathrm{b}}$ \\
20 & 2.3 & $230^{\mathrm{b}}$ \\
22 & 2.5 & $250^{\mathrm{ab}}$ \\
24 & 2.6 & $260^{\mathrm{a}}$ \\
30 & 3.0 & $300^{\mathrm{a}}$ \\
SEM & 2.10 & 24.05 \\
\hline
\end{tabular}

Means bearing different a,b superscript within a column are significantly different $(\mathrm{p}<0.05)$

Table 3: Effect of age of male Catfish broodstock on quantity of milt produced

\begin{tabular}{lll}
\hline Age (Months) & Weight $(\mathrm{Kg})$ & Milt weight $(\mathrm{g})$ \\
\hline 16 & 2.0 & $200^{\mathrm{b}}$ \\
18 & 2.2 & $220^{\mathrm{b}}$ \\
20 & 2.4 & $240^{\mathrm{b}}$ \\
24 & 2.8 & $280^{\mathrm{a}}$ \\
30 & 3,0 & $300^{\mathrm{a}}$ \\
32 & 3.2 & $320^{\mathrm{a}}$ \\
SEM & 2.18 & 2.70 \\
\hline
\end{tabular}


Means bearing different a,b superscript within a column are significantly different $(\mathrm{p}<0.05)$

For the female, the older the broodstock, the higher the quantity of eggs produced. Growth of fry obtained from younger and older broodstock was significantly different $(p<0.05)$ being higher in the older broodstock. This is consistent with the report of catfish brookstock Management (2010) which indicated that although catfish may mature at 2 years, they must be at least 3 years old and weigh at least $1.4 \mathrm{~kg}$ for reliable spawning. Fish, 4 to 6 years old, weighing between 1.8 and $3.6 \mathrm{~kg}$ are considered prime spawners. The report however, indicated that older fish produce fewer eggs per body weight. The female brood fish with the highest weight and age had higher fertilization with almost $80 \%$ survival rate when compared to the youngest (15 months) female brood fish.

Although there was steady increase in weight gain over a period of four (4) weeks, as shown in Table 4, the growth rate was faster for fry obtained from older female broodstock (22, 24 and 30 months) signifying that growth (0-4Wks) performance of catfish fry was better from eggs of older females. Okoye (1994), also reported similar result and attributed such differences in growth to differences in age and maturation of the broodstock. In this study, the broodstock were fed the same diet all through so the difference in growth rate of the fry could mainly be accounted for by differences in the ages of the broodstock

Table 4: Growth (g) Performance of Catfish (Clarias gariepinus) Fry (0-4wks)

\begin{tabular}{lllll}
\hline Age of female (Months) & Week 1 & Week $2.67^{\mathrm{c}}$ & Week 3 & Week 4 \\
\hline 15 & $2.00^{\mathrm{c}}$ & $3.07^{\mathrm{c}}$ & $5.33^{\mathrm{c}}$ & $10.00^{\mathrm{bc}}$ \\
18 & $3.00 \mathrm{c}$ & $4.67^{\mathrm{c}}$ & $6.33^{\mathrm{c}}$ & $12.00^{\mathrm{bc}}$ \\
20 & $4.42^{\mathrm{b}}$ & $6.33^{\mathrm{b}}$ & $9.00^{\mathrm{bc}}$ & $15.83^{\mathrm{b}}$ \\
22 & $4.57^{\mathrm{b}}$ & $7.00^{\mathrm{b}}$ & $8.00^{\mathrm{bc}}$ & $18.00^{\mathrm{b}}$ \\
24 & $5.00^{\mathrm{a}}$ & $8.80^{\mathrm{b}}$ & $13.07^{\mathrm{a}}$ & $24.00^{\mathrm{a}}$ \\
30 & $5.50^{\mathrm{a}}$ & $11.00^{\mathrm{a}}$ & $17.00^{\mathrm{a}}$ & 2.7 \\
SEM & 0.84 & 1.10 & 1.82 & \\
\hline
\end{tabular}

Means bearing abc superscript within a column are significantly different $(\mathrm{P}<0.05)$

\section{Conclusion and Recommendation}

It is concluded from this study that age of female and male catfish affects the quantity of eggs and milt produced. It is recommended that hatchery operators use older broodstock (24 -30 months) in order to obtain larger quantity of eggs or milt, good hatchability and growth of their fry

\section{References}

[1]. A Practical Guide to Nutrition, Feeds and Feeding of catfish (2011). Bulletin $1113.22^{\text {nd }} \quad$ ed . http://msucares.com/aquaculture/catfish/feed.html.webmaster@ext.msstste.edu

[2]. Bolorunduru P.1., Aribido S.O., Bawa G. S., Amos T. T. and Jegede O.C. (2001). Food Security and Poverty Alleviation Application of Livestock cum fish Culture Models in Transforming Rural Agriculture. Proceeding of the $26^{\text {th }}$ Annual Conference of Nigeria Society for Animal Production Pg. 189-191

[3]. Channel Catfish Broodfish Management SRAC Fact Sheet No 1802 (2010). http://msucares.com/aquaculture/catfish/production.html . webmaster@ext.msstate.edu

[4]. Jokthan, G. E. (2010). Integrating Aquaculture with Horticulture. Entrepreneurial Skill Acquisition Training Workshop: Fish Farming, Processing and Marketing. Held at the Nigerian Institute for Oceanography and Marine Research $23^{\text {rd }}-26^{\text {th }}$ Feb. 2010

[5]. Okoye, F.C. (1994). Status of fish farming in Nigeria. Report of National Aquaculture Diagnostic Survey. 1994

[6]. Omole, A.J., Fapohunda, J.B., Bankole M., Owosibo, A. and Omidiran V.A., (2006). Practical Catfish Nutrition and Growth Guide. Green Choice Agric Publication.

[7]. SAS. (2006). Institute inc. SAS/STAT user's guide. 6.03 Edition, Gray NC, USA. 